\title{
Performance Evaluation of Introducing Electronic Commerce into Organic Agricultural Products
}

\author{
Jen-Der Day \\ Department of Industrial Engineering and Management, \\ Kaohsiung University of Applied Sciences (KUAS), \\ Taiwan, ROC \\ Email: jdd@cc.kuas.edu.tw \\ Chich-Jen Shieh, \\ Institute of Quantitative Economics, \\ Huaqiao University Quanzhou 362021, Fujian, China \\ Email: charleshieh@hqu.edu.cn
}

\author{
Hsien-Tang Tsai \\ Professor, Department of Business Management, \\ National Sun Yat-sen University, Taiwan ROC \\ Email: htt@mail.nsysu.edu.tw \\ (Corresponding author)
}

\begin{abstract}
The introduction of electronic commerce allows consumers collecting multiple and complete product information to induce the purchase motivation. In addition, the electronic commerce appears multiple and efficient product delivery from manufacturer-retailer channels to consumers and largely reduce transportation costs. Since the introduction of electronic commerce is an innovation to affect the entire operation of organic farms, 12 organic farms published in Catalog of Organic Vendors in Taiwan are sampled as the research subjects in this study. The research results conclude that 1.Little Ladybird Organic Farm presents the best overall efficiency, followed by Tienshanlin Organic Farm, and Nungchunchen Farm the worst and 2.the effects of production technology of total factor productivity, pure technical efficiency change, scale efficiency between periods, and technological change between periods on the changes and future directions of organic farms are acquired through various Malmquist efficiency analyses. According to the conclusion, suggestions are proposed, expecting to find out problems and difficulties related to the introduction of electronic commerce and give correspondent suggestions. It is expected to provide reference for those who intend to involve in organic agriculture with electronic commerce as well as offer overall reference of customer service for electronic commerce suppliers.
\end{abstract}

Keywords - Land size, Produce, Net operating revenue, Pre-tax income

\section{INTRODUCTION}

With the advanced development of information, electronic commerce has become an important channel providing enterprises or individuals with product information, media, and service. Since the Internet shows the characteristics of cross-boundary, full-time, interactivity, and richness, the introduction of electronic commerce allows consumers collecting multiple and complete product information to further induce the purchase motivation. In addition to enhancing channels of distribution and service, it could reduce operation costs, promote operational efficiency, and enhance customer satisfaction for enterprises. Electronic commerce does not simply become the major development on the Internet, but also offers more convenient and efficient trading, appealing numerous operators to invest in electronic commerce. Internet has attracted lots of retailers participating in the competition of online shopping, more and more surfers joining in the consuming behavior of online shopping, and physical businesses more actively investing in the operation of e-shops. The emergence of national health has organic produce boom in Taiwan. Among various organic vegetable purchase channels, home delivery consumers show the highest satisfaction and loyalty that they are willing to recommend organic food to others, purchase products with specific brand, business, and certification, and present longer period and higher consumption rate on organic vegetable. In this case, home delivery is a key opportunity to expand organic food markets. Promoting organic food home delivery businesses through electronic commerce and establishing online order service websites for online orders and home delivery service could rapidly and largely attract potential organic food consumers to expand the organic food market. Selling organic produce online is comparatively more complex than general daily necessities. In comparison with other industries, most organic agricultural production in Taiwan is petty farmers that the production cost is higher. Besides, the profit in the entire supply chain, from manufacturer-retailer channels to consumers, is often exploited by intermediaries. Electronic commerce could directly connect suppliers and buyers to trade through the Internet, without being restricted to time and location, that it presents real-time update and interactivity, effectively reduces costs, enhances product quality and service delivery speed, opens new markets, and rapidly provides service. As a result, electronic commerce not only could overcome the shortcomings of produce being easily spoiled and hard to preserve, but could also multiply enhance the product delivery efficiency from manufacturer-retailer channels to consumers and largely reduce transportation costs. Any decisions made by enterprises are expected to achieve the profit-making goal that the benefits would eventually reflect to the financial performance. Financial indicators therefore are selected as the performance evaluation standard in this study for introducing electronic commerce into organic agricultural products. It is expected to find out problems and difficulties related to the introduction of electronic commerce, provide correspondent suggestions, as well as offer reference for those who intend to get in the organic agriculture with electronic commerce and overall reference of customer service for electronic commerce suppliers. 


\section{MATERIAL AND METHODS}

\section{A. Literature review}

\section{Organic agriculture}

Nidumolu et al. (2014) mentioned that organic agriculture was also called ecological agriculture, low input agriculture, biological agriculture, nature farming, regenerative agriculture, alternative agriculture, or sustainable agriculture depending on the definition in regulations in different countries or agricultural associations. Council of Agriculture and Agriculture and Food Agency in Taiwan use Organic Agriculture. Bandara et al. (2013) indicated that organic agricultural production focused on ecological balance and environmental protection that synthetic substances, such as pesticides, fertilizers, and growth hormone, were not used; instead, integrated farming and rotation tillage were used to have individual farms independently become an ecological system. Kumar et al. (2012) regarded organic farming as the cultivation beneficial to environment and soil that it could enhance soil biodiversity, filter insecticides, did not allow the use of artificial fertilizers, and produce through special management. Kadam et al. (2014) defined organic agriculture as the agriculture following the principles of recycling and sustainably utilizing natural resources, not using synthetic chemicals, stressing on the management system of water and soil resource conservation and ecological balance, and achieving the production of natural and safe produce.

\section{Electronic commerce}

Kang et al. (2015) regarded electronic commerce as the combination of commercial behaviors of purchasing and selling products and services through computer Internet so as to satisfy the demands of organizations, businessmen, and consumers, reduce costs, enhance product and service quality, and reinforce the delivery of service efficiency. From the essence of electronic commerce and the aspect of digitalization, Lagerkvist et al. (2012) stated that domestic researchers considered four major circulation systems as the composition of electronic commerce, including "business flow" for trading, "logistics" for distribution, "payment flow" for transfer payment, and "information flow" for data value-added and delivery. In the process of an organization promoting electronic commerce, the promotion and support of executive leaders as well as organizational members' professional knowledge and ability of information and attitudes towards information technology would affect the introduction of electronic commerce. Chang \& Yang (2011) defined electronic commerce as online purchase, sales, or product, service, and information exchange through computer Internet; or, it could be defined from the viewpoints of cooperation and social community. 1. From the aspect of cooperation, electronic commerce was the structure providing inter-organization and intra-organization cooperation. 2. From the aspect of social community, electronic commerce was a place offering social community members to mutually learn, interact, and cooperate. Martinez et al. (2010) considered that electronic commerce referred to any electronic commercial activities as well as the extension of electronic data interchange (EDI) and value-added network (VAN). Generally speaking, "electronic commerce" could be both parties trading through computer Internet. Electronic commerce is defined in this study as the degree of an enterprise using Internet technology, including the functions of email, Internet, corporate website, and online shopping, for examining the degree of an enterprise using Internet technology. In general, electronic commerce plays the role of linking product trading from order (business flow), product delivery (logistics), to payment and receivable (payment flow) (Sarkis et al., 2011). In this case, information flow is closely related to business flow, payment flow, logistics, and human resource flow in the electronic commerce environment. The higher information content and reliability and an enterprise being able to utilize information technology for instantaneously and rapidly adjusting the information content and delivering documents to shorten the response time and enlarge the IT contribution would facilitate the enterprise introducing electronic commerce.

\section{Performance evaluation}

Financial performance is usually measured with financial indicators. Finance is a tool to evaluate corporate performance (Kirchhoff et al., 2011). The measurement of business performance aims to have managers inspect the organization for the achievement of goals as well as judge the progress of corporate performance. As the idea of business performance is broad and abstract, the measurement standard is distinct. It is generally classified into financial indicators (e.g. return on investment, return on sales, income growth rate) (Hong, 2011) or non-financial indicators (e.g. customer satisfaction, new product listed or policy goal rate, employee efficiency, R\&D of produce process) (Unruh \& Ettenson, 2010). Generally, enterprises would measure business performance with financial indicators, such as return on investment, sales growth rate, and return on asset. Since profit-making is the purpose of enterprises, it allows the sustainable management of enterprises. Any decisions made by enterprises are expected to achieve the goal of making profits that final benefits are often reflected on financial performance. For this reason, financial indicators are selected as the performance evaluation standard of business operation in this study.

$\mathrm{Li}$ (2011) divided organizational performance into financial performance and operation performance. Financial performance measured the achievement of an enterprise in the economic goal with output-based financial indicators, such as sales growth, return on investment, and earnings per share. Operation performance, or non-financial performance, was the evaluation index to measure technical efficiency, e.g. market share, new product introduction, product quality, and added-value creation. There were several standards for the evaluation of financial indicators. According to research subjects and areas, a single concept, such as return on asset (ROA), return on sales (ROS), return on equity (ROE), and sales growth rate, could be applied (Zaabi et al., 2013). Financial indicators mentioned by Zhu et al. (2012) contained net marginal profit, return on asset (ROA), return on investment (ROI), overall competitive position, and general profit making. Mirhedayatiana et al. (2014) divided financial indicators into return on investment (ROI), return on sales, gross profit, cash flow, earnings per share, return on shareholder, revenue growth, and sales growth. In the field study, Zhu et al. (2012) discovered that the deeper informatization and the larger operating procedure systematization and IT investment in an enterprise, the better business performance appeared after the introduction of electronic commerce.

\section{B. Methodology}

\section{Research subject}

Since the introduction of electronic commerce is an innovation and would affect the operation of an organic farm (including the established company), 12 organic farms published on Catalog of Organic Vendors in Taiwan 
(http://organic.niu.edu.tw/farm/) are sampled as the research subjects in this study.

Modified Delphi Method is applied in this study to enhance the benefit of questionnaire survey. The experts directly focus on the research topic to objectively select input/output variables. Total 5 input/output variables are selected in this study, and 12 DMUs are available. All variable data are from public income statements, prospectuses, and annual reports of the organic farms.

\section{Data Envelopment Analysis}

Data Envelopment Analysis, a mathematical model developed by Charnes et al. in 1978 to evaluate efficiency, estimates the efficiency with non-default production functions, instead of default functions, and calculates the production frontier curve with mathematical planning model. The actual output value compared with original production functions is the so-called efficiency. Envelopment is the theoretical basis of DEA. The basic principle was established based on Pareto Optimality proposed by Pareto, an Italian economist, who defined "it is impossible to make any one individual better off without making at least one individual worse off." DEA is a multi-output multi-input efficiency model which does not consider weight setting in advance, gradually comparing all DMUs with the quantization result to select a better DMU and then drawing a curve of all efficient DMUs as the production frontier. The distance between observation and efficiency envelope of individual DMU is calculated for the relative efficiency. In sum, DEA is a relative indicator which measures the efficiency of each organization according to efficiency frontiers constructed with actual observation and the difference between observation and efficiency frontiers as the relative inefficiency, through linear planning.

3. Definition of input/output variable

(1) Input variable

a. Number of employee: Total number of employee in organic agriculture includes sales (field personnel) and administration staff (back office staff).

b. Electronic commerce introduction cost: Referring to various expenses when introducing electronic commerce into organic agriculture.

c. Land size: The cultivation land area for organic agriculture. (2) Output variable :

a. Net operating revenue: Gross operating revenue - sales return and allowance.

b. Pre-tax income: Pre-tax income $=$ operating income + non-operating revenue (loss). It reveals whether a company makes money before tax.

\section{RESULTS}

\section{A. Empirical analysis}

1. Relative efficiency analysis

Table 1 shows the relative efficiency of organic farms. Little Ladybird Organic Farm appears the best overall efficiency (1.00), followed by Tienshanlin Organic Farm (0.92), and Nungchunchen Farm the worst (0.73).

Little Ladybird Organic Farm presents the best pure technical efficiency, followed by Tienshanlin Organic Farm (0.93), and Joanne Organic Farm the worst (0.73).

Little Ladybird Organic Farm shows the best scale efficiency (1.00), followed by Tienshanlin Organic Farm (0.91), and Nungchunchen Farm the worst (0.71).
Table 1: Relative efficiency of organic farms

\begin{tabular}{|l|c|c|c|}
\hline Organic farm & $\begin{array}{c}\text { Overall } \\
\text { efficiency }\end{array}$ & $\begin{array}{c}\text { Pure } \\
\text { technical } \\
\text { efficiency }\end{array}$ & $\begin{array}{c}\text { Scale } \\
\text { efficiency }\end{array}$ \\
\hline $\begin{array}{l}\text { Mood Organic } \\
\text { Farm }\end{array}$ & 0.87 & 0.86 & 0.88 \\
\hline Pure Green Farm & 0.82 & 0.83 & 0.82 \\
\hline $\begin{array}{l}\text { Little Ladybird } \\
\text { Organic Farm }\end{array}$ & 1.00 & 1.00 & 1.00 \\
\hline $\begin{array}{l}\text { Hsingyun } \\
\text { Organic Farm }\end{array}$ & 0.90 & 0.92 & 0.88 \\
\hline $\begin{array}{l}\text { Nungchunchen } \\
\text { Farm }\end{array}$ & 0.73 & 0.75 & 0.71 \\
\hline $\begin{array}{l}\text { Tienshanlin } \\
\text { Organic Farm }\end{array}$ & 0.92 & 0.93 & 0.91 \\
\hline $\begin{array}{l}\text { Kuantzutsai } \\
\text { Organic Farm }\end{array}$ & 0.89 & 0.90 & 0.87 \\
\hline Chihsien Farm & 0.80 & 0.83 & 0.77 \\
\hline $\begin{array}{l}\text { Shangmachi } \\
\text { Organic Farm }\end{array}$ & 0.85 & 0.83 & 0.86 \\
\hline $\begin{array}{l}\text { Joanne Organic } \\
\text { Farm }\end{array}$ & 0.78 & 0.73 & 0.82 \\
\hline Tsaiho Farm & 0.84 & 0.85 & 0.83 \\
\hline $\begin{array}{l}\text { Hahiti Organic } \\
\text { Farm }\end{array}$ & 0.90 & 0.91 & 0.89 \\
\hline
\end{tabular}

\section{Malmquist Productivity Index analysis}

Table 2 shows various Malmquist efficiency analyses, where the organic farms, except Little Ladybird Organic Farm, appear total factor productivity less than 1, revealing the decrease in productivity. In terms of pure technical efficiency change, Mood Organic Farm, Pure Green Farm, Little Ladybird Organic Farm, Hsingyun Organic Farm, Kuantzutsai Organic Farm, Chihsien Farm, Joanne Organic Farm, and Hahiti Organic Farm show improved efficiency, while the rest appear worsening efficiency. Regarding scale efficiency between periods, Little Ladybird Organic Farm moves towards long-term optimal size, while the rest appear less than 1 , presenting the management moving far away from long-term optimal size. Moreover, it is found that the organic farms have improved the production technology in technological change between periods.

Table 2: Malmquist efficiency analysis

\begin{tabular}{|c|c|c|c|c|}
\hline Organic farm & $\begin{array}{c}\text { Technological } \\
\text { change } \\
\text { between } \\
\text { periods } \\
\text { TECHCH }\end{array}$ & $\begin{array}{c}\text { Pure } \\
\text { technical } \\
\text { efficiency } \\
\text { change } \\
\text { PECH }\end{array}$ & $\begin{array}{c}\text { Scale } \\
\text { efficiency } \\
\text { between } \\
\text { periods } \\
\text { SECH }\end{array}$ & $\begin{array}{c}\text { Total factor } \\
\text { productivity } \\
\text { change } \\
\text { TFPCH }\end{array}$ \\
\hline $\begin{array}{c}\text { Mood Organic } \\
\text { Farm }\end{array}$ & 0.91 & 0.87 & 0.90 & 0.90 \\
\hline $\begin{array}{c}\text { Pure Green } \\
\text { Farm }\end{array}$ & 0.86 & 0.85 & 0.85 & 0.86 \\
\hline $\begin{array}{c}\text { Little } \\
\text { Ladybird } \\
\text { Organic Farm }\end{array}$ & 1.04 & 1.03 & 1.06 & 1.12 \\
\hline $\begin{array}{c}\text { Hsingyun } \\
\text { Organic Farm }\end{array}$ & 0.95 & 0.93 & 0.84 & 0.95 \\
\hline $\begin{array}{c}\text { Nungchunchen } \\
\text { Farm }\end{array}$ & 0.78 & $0.74-$ & 0.72 & 0.78 \\
\hline $\begin{array}{c}\text { Tienshanlin } \\
\text { Organic Farm }\end{array}$ & 0.95 & $0.92-$ & 0.90 & 0.96 \\
\hline $\begin{array}{c}\text { Kuantzutsai } \\
\text { Organic Farm }\end{array}$ & 0.93 & 0.91 & 0.89 & 0.91 \\
\hline
\end{tabular}




\begin{tabular}{|c|c|c|c|c|}
\hline Chihsien Farm & 0.84 & 0.84 & 0.75 & 0.88 \\
\hline $\begin{array}{c}\text { Shangmachi } \\
\text { Organic Farm }\end{array}$ & 0.86 & $0.81-$ & 0.88 & 0.87 \\
\hline $\begin{array}{c}\text { Joanne } \\
\text { Organic Farm }\end{array}$ & 0.82 & 0.75 & 0.85 & 0.83 \\
\hline Tsaiho Farm & 0.86 & $0.83-$ & 0.85 & 0.87 \\
\hline $\begin{array}{c}\text { Hahiti Organic } \\
\text { Farm }\end{array}$ & 0.94 & 0.92 & 0.86 & 0.97 \\
\hline
\end{tabular}

\section{DISCUSSION}

After the survey, total 12 organic farms are selected as valid samples for this study. Data Envelopment Analysis is applied to evaluate the performance on the introduction of electronic commerce into organic farms. The research results reveal that the organic farms show the pure efficiency mean less than 1 that they could enhance technical efficiency after improving pure technical efficiency. In this study, Little Ladybird Organic Farm shows better performance on the introduction of electronic commerce, possibly because of the 19-year management. The farm is built along the sloping field and the side slope is planted repellent crops and isolation crops. Under the insistence of the farm owner, organic cultivation is utilized for the production to survive with the nature. In the beginning of the establishment, it presented favorable interaction with MOA International, the certification institute, and became the first certification member; the farm was also certified by MOA International. Promoting organic produce through electronic commerce is a proper method, as it provides good online product sales functions, e.g. online shopping and catalogue, and presents business information collection, e.g. understanding consumer behaviors through online enquiry, discussion board, and message board and enhancing customer satisfaction by interacting with consumers. Regarding payment flow, it is necessary for either suppliers or consumers to provide a convenient and secure trading mechanism and inform consumers of the entire trading process and capital flow to promote consumer confidence.

Aiming at introducing electronic commerce into organic farms, the following suggestions are proposed in this study.

A. Most farms show independent production and marketing or cultivate and deliver to certain businesses. Nevertheless, it is rather difficult to control the produce yield because of climate that they cannot predict the stocks, as manufacturing industry, to circulate on the Internet. When planning electronic commerce, they are not online shopping oriented, but start from simple website structure to reinforce the brand image and information exchange, such as establishing company introduction, online catalogue, news platform, online enquiry, message board, discussion area, and email, and promote the electronic commerce planning according to the farm size, e.g. online shopping, inventory system, and member prefecture which require more human resource management functions, in order to expand the electronic commerce domain step by step.

B. When offering customer services, electronic commerce suppliers should understand the industrial characteristics of entrusted enterprises to provide convenient Internet order interface, product promotion program, and business information collection support. Electronic commerce suppliers should enhance the professional knowledge and technology about internal information of entrusted enterprises or offer professional information advisers for assisting the digitalization. Business owners can be reinforced the support attitudes towards electronic commerce, promoted the professional knowledge and

technology of electronic commerce, and enhanced the employees' support attitudes towards electronic commerce.

C. The convenience, security, and stability of payment systems are emphasized for introducing electronic commerce into organic farms that multiple trading systems, convenient trading systems, and healthy trading systems should be provided. Rich and multiple organic produce information, reliable organic produce related information platforms, and real-time newly listed organic produce information are necessary for product information flow.

\section{Reference}

[1] Bandara, B. M. D., Abeynayake, P. N. R., Bandara, L \&Anjalee, G. H. I. (2013), Farmers's perception and willingness to pay for pesticides concerning quality and efficacy. The Journal of Agricultural Sciences, 8(3), 153-160.

[2] Chang, K. F. \& Yang, H.-W., (2011), Utilizing Mens-end chain to explore customers' preference in purchasing bundle. Information Technology Journal, 10(8), 1563-1570.

[3] Hong, C. J. (2011), Inter-organizational relationships and knowledge sharing in green supply chains-Moderating by relational benefits and guanxi, Transportation Research Part E: Logistics and Transportation Review 47(6), 837-849.

[4] Kadam, V. Shukla M. \&Ubale, A. (2014), Prevention of downy mildew disease in grape field.International Journal of Advances in Englineering\& Technology. 7(1), 200-205.

[5] Kang, G. Fang C., \& Zhang, S. (2015), Empirical research on factors that influence the behavior decision of repeated seed purchase for farmers - field investigation based on 519 vegetable farmers in Wuhan city. SHS Web of Conferences, Wuhan, Hubei, China: Huazhong Agricultural University.

[6] Kirchhoff, S., Heather, S., Sanderson, J., Sultanbawa Y. \&Gething, K. (2011), Increasing vegetable consumption: a means-end chain approach. British Food Journal. 113(8), 1031-1044.

[7] Kumar, S., Teichman, S., \&; Timpernagel, T. (2012), A green supply chain is a requirement for profitability, Int. J. Prod. Res., $50(5), 1278-1296$.

[8] Lagerkvist, C. J., Ngigi, M., Okello, J. J. \&Karanja, N., (2012), Means-end chain approach to understanding farmers' motivations for pesticides use in leafy vegetables: The case of kale in peri-urban Nairobi, Kenya. Crop Protection, 39, 2-80.

[9] Li, Y. (2011). Research on the performance measurement of green supply chain management in China, Journal of Sustainable Development, 4 (3), 101-107.

[10] Martinez, S., Hand, M., Da Pra, M., Pollack, S., Ralston, K., Smith, T., Vogel, S., Clark, S., Lohr, L., Low, S., and Newman, C. (2010), Local Food Systems: Concepts, Impacts, and Issues. U.S. Department of Agriculture, Economic Research Service, ERR-97.

[11] Mirhedayatiana, S. M. Azadib, M. Saenb, R.S. (2014), A novel network data envelopment analysis model for evaluating green supply chain management, International Journal of Production Economics 147, 544-554.

[12] Nidumolu, R., Ellison, J., Whalen, J., \&; Billman, E. (2014) The Collaboration Imperative,Harvard Business Review.

[13] Sarkis, J., Zhu, Q., \&; Lai, K.H. (2011). An organizational theoretic review of green supply chain management literature, International Journal of Production Economics, 130 (1), 
$1-15$.

[14] Unruh, G. and Ettenson, R. (2010).Winning in the green frenzy. Harvard Business Review, 88(11): 110-16.

[15] Zaabi, Al., Shaikha, Dhaheri, N. A., \&; Diabat, A. (2013).

Analysis of interaction between the barriers for the implementation of sustainable supply chain management. The International Journal of Advanced Manufacturing Technology $1-11$.
[15] Zhu, Q., Sarkis, J., \&; Lai, K.H. (2012). Examining the effects of green supply chain management practices and their mediations on performance improvements, International Journal of Production Research, 50 (5), 1377-1394.

[16] Zhu, Q., Sarkis, J., \&; Lai, K.H. (2012).Internationalization and environmentally-related organizational learning among Chinese manufacturers, Technological Forecasting and Social Change, 79 (1), 142-154. 